Oil extraction imperils Africa's Great Lakes

Peer-reviewed author version

Verheyen, Erik; Abila, R.; Akoll, P.; Albertson, C.; Antunes, D.; Banda, T.; Bills, R.; Bulirani, A.; Manda, A. Chocha; Cohen, A. S.; Cunha-Saraiva, F.; Derycke, S.;

Donohue, I.; Du, M.; Dudu, A. M.; Egger, B.; Fritzsche, K.; Frommen, J. G.; Gante, H. F.; Genner, M. J.; Haerer, A.; Hata, H.; Irvine, K.; Mwapu, P. Isumbisho; de Bisthoven, L. Janssens; Jungwirth, A.; Kaleme, P.; Katongo, C.; Kever, L.; Koblmueller, S.; Konings, A.; Lamboj, A.; Lemmel-Schaedelin, F.; Schiaffino, G. Machado; Martens, K.; Mulungula, P. Masilya; Meyer, A.; More, H. L.; Musilova, Z.; Bukinga, F. Muterezi; Muzumani, R.; Ntakimazi, G.; Okello, W.; Phiri, H.; Pialek, L.; Plisnier, P. D.; Raeymaekers, J. A. M.; Rajkov, J.; Rican, O.; Roberts, R.; Salzburger, W.; Schoen, I.; Sefc, K. M.; Singh, P.; Skelton, P.; Snoeks, J.; Schneider, K.; Sturmbauer, C.; Svardal, H.; Svensson, O.; Dowdall, J. Torres;

Turner, G. F.; Tyers, A.; van Rijssel, J. C.; VAN STEENBERGE, Maarten; VANHOVE, Maarten; Weber, A. -T.; Weyl, O.; Ziegelbecker, A. \& Zimmermann, H. (2016) Oil extraction imperils Africa's Great Lakes. In: SCIENCE, 354(6312), p. 561-562.

DOI: 10.1126/science.aal1722

Handle: http://hdl.handle.net/1942/23763 


\section{Oil extraction imperils Africa's Great Lake}

As the world's demands for hydrocarbons increase (1), remote areas previously made inaccessible by technological limitations are now being prospected for oil and gas deposits. Virtually unnoticed by the public, such activities are ongoing in the East African Great Lakes region, threatening these ecosystems famed for their hyper-diverse biota, including the unique adaptive radiations of cichlid fishes (2). Countries in the region see exploitation of hydrocarbon reserves as a vital economic opportunity. In the Lake Albert region of Uganda, for example, the government foresees a $\$ 3.6$ billion oil profit per year starting in 2018-a sum almost as high as the country's current annual budget (3). However, oil extraction in the East African Great Lakes region poses grave risks to the environment and local communities.

The thousands of oil spills reported in Nigeria (4) demonstrate that the extraction and transport of oil is prone to accidents. This is especially bad news for the African Great Lakes because they are virtually closed ecosystems. For example, for Lake Tanganyika that contains about one fifth of the world's surface freshwater, the flushing time is 7000 years (5), which implies that the recovery from an oil spill could take millennia. To make matters worse, the lakes' location in a remote part of the world would impede a quick and effective reaction to an oil spill. Appropriate infrastructures are currently unavailable at the lakes, and bringing in heavy equipment at the time of a spill would be cumbersome, logistically impossible, or prohibitively expensive.

An oil spill would markedly affect the health, water supply, and food security of local communities (6). More than 10 million people depend on Lake Tanganyika alone for fisheries and water resources and many more along the Congo River, where the lake drains to, are highly dependent on the lakes' ecosystem (7). An oil spill in these lakes would be a global catastrophe for biodiversity. Combined, these lakes are home to thousands of species, almost all of them endemic (2). An accident might deal a final blow to these ecosystems, which have already been rendered fragile by anthropogenic stressors such as overfishing, deforestation, and global warming (8).

Finally, large parts of the East African region still lack political stability and security (9). In addition to the possibility of accidents, competition for hydrocarbon resources could lead to sabotage, as unfortunately frequently observed in the Niger delta.

We are concerned that the risks associated with the intended exploitation of fossil hydro- carbons in the East African Great Lakes region are seriously underestimated. We urge the countries involved in these undertakings to engage with the scientific and lake management communities to identify strong mitigation and control measures that could be put in place before hydrocarbon production begins. Local governments should foster alternative, sustainable plans to develop the region in accordance with the United Nations Sustainable Development Goals (10). To this end, the local population, regional stakeholders, governments, nongovernmental organizations, and scientists must cooperate to develop economically and ecologically viable strategies for the region, as is currently being attempted for the Virunga National Park in the DR Congo (11).

Cichlid Science 2015 Meeting and supporters (Suppl. Mat.)

*Corresponding author. Erik Verheyen. Email: erik.verheyen@naturalsciences.be

REFERENCES

1.International Energy Agency, Oil Market Report (2016);

https://www.iea.org/oilmarketreport/omrpublic/ 2.W. Salzburger, B. van Bocxlaer, A.S. Cohen, Annu. Rev. Ecol. Evol. Syst. 45, 519 (2014).

3.Daily Monitor, Uganda to earn Shs9 trillion from oil annually - Tullow, September 14 (2014) http://www.monitor.co.ug/News/National/Ugan da-to-earn-Shs9-trillion-from-oil-annually--Tullow/688334-2451478-rag0a9/index.html.

4.Nigerian Oil Spill Monitor (https://oilspillmonitor.ng/).

5.L. R.H. Spigel, G.W. Coulter, G.W., 1996, in The Limnology, Climatology and Paleoclimatology of the East African Lakes, T.C. Johnson, E.O. Odada, eds. (Gordon and Breach Publ, Amsterdam, 1966), pp 103-140.6. NCF/WWF/IUCN, "Niger Delta Natural resources damage assessment and restoration project scoping report, May 2006" [Nigerian Conservation Foundation, UK World Wildlife Federation, and International Union for Conservation of Nature, Commission on Environmental, Economic, and Social Policy from the Federal Ministry of Environment (Abuja), 2006].

7.H. Mölsä, J. E. Reynolds, E. J. Coenen, O. V. Lindqvist, Hydrobiologia 407, 1-24 (1999)

8. A. S. Cohen et al., Proc. Natl. Acad. Sci. U.S.A. 113, 9563 (2016)

9. A. Adusei, African Security Rev. 24, 332 (2015).

10. United Nations, 17 goals to transform our World (2015)

(http://www.un.org/sustainabledevelopment/sustai nable-development-goals/)

11. Global Witness, "Protecting Virunga National Park from oil companies" (2016); www.globalwitness.org/en/campaigns/oil-gasand-mining/protecting-virunga-national-parkoil-companies/.

SUPPLEMENTARY MATERIALS

www.sciencemag.org/content/xxx/xxxx/xxx/suppl/D C1

Full author list

10.1126/science.aal1722

Fig. 1: African Great Lakes region, and examples of the local communities and the endangered biodiversity in these lakes. (photographs by $\mathrm{Ad}$
Konings are available in their original resolution) 